\title{
Expanding Horizons through Education: Excerpts from the Life of a Convict Criminologist Charles M. Terry
}

$\mathrm{E}$ ducation is often associated with light, knowledge, understanding, and awareness. Learning, especially when sparked by enthusiasm and motivation, can be an exciting, rewarding journey. With education comes new ideas, ways of seeing, beliefs, possibilities, and action. Ignorance, on the other hand, is associated with darkness. Unable to ask questions or wonder about anything beyond their limited worlds, the ignorant tend to grope through life. Often they are led like sheep. Whether they are steered one way or another by television, people at work, their families, or by anyone else, they maintain a sense of safety and purpose by blindly following an unthinking pack of others they identify as being similar to themselves.

In many ways I have been in the process of overcoming this "herd mentality" (Fromm, 1976) for quite some time. All my efforts to do so have involved some form of education. This article is a brief overview of my personal story as it relates to how I have been affected by learning. It includes excerpts from my life history dating back to when I became a full blown heroin addict at the age of eighteen; four prison commitments for drug related crimes in California and Oregon resulting in a roughly twelve years behind bars; my college education which began in prison in 1986, and culminated with a Ph.D. from the University of California in 1999; and a bit about my experiences as a college professor, and my associations with other ex-convict academics.

Before beginning, however, I think it is important to note that in 1984 I was sentenced to the Oregon State Prison (OSP) for burglary. This would be my fourth prison commitment. Like the other three, all which took place in my home state of California during the 1970s, my conviction was related to the fact that, as a heroin addict, I was unable to live a law-abiding lifestyle. It was during the six and a half years I did in that system before being paroled that I began learning things that dramatically altered the very narrow, distorted perceptions I had about history, life, people, and myself.

\section{The WaY IN}

Like everyone, I have been learning all my life. Yet what we learn reflects how we interpret what we are exposed to: our self-concepts, values, and sense of 
purpose in life. My oldest memories leave me with the impression that I learned to feel differently from others and out of place at a very young age. I remember playing hooky in kindergarten because I thought I did not like school. Rather than show up for class, I hid in the bushes beyond a chain link fence that encompassed the playground. (Little did I know that in the future I would be living on the high side of C-block at OSP, where I would observe people in the yard through the bars of my cell and the windows of the cellblock). Unpleasant feelings flowed through me as I watched the other kids playing during recess. They appeared to be having fun and, however hard I tried, I could not understand why. By age twelve, I was hanging around with youngsters who, like me, did not thrive well in a school environment. Instead, we smoked cigarettes, listened to rock and roll music, and surfed every chance we could. By the time I was fifteen in 1967, I was smoking pot and using other drugs like LSD, speed, and alcohol. At the tender age of eighteen, I injected heroin for the first time.

The first time I felt something burn my body, I knew I had to keep hot things away from my skin. Similarly, once I felt the euphoric effects of heroin, I instantly knew I had found my purpose in life. I remember actually telling the guy who gave me my first shot, "Man, this feels so good. I can't believe I've been doing anything in my life other than using this stuff." When I was under the influence of that drug I was fixed. All of a sudden I was in love with the world. As never before I felt connected to other human beings. I would greet old ladies as they walked down the street. I would say "hi" to little kids and give them dimes and nickels for candy. Whether I was working, having sex, nodding out somewhere, or stealing, whenever I was high I was okay with my place in the universe. For the next twenty years I did my best to "chase the dragon" and to satisfy my desire for what came to be my reason for living. As fate would have it, however, I spent the bigger part of those twenty years behind bars.

Before a year had passed after that first shot, my entire social network had been turned on its head. No longer did I have anything in common with the surfers and hippie types I hung out with before. In their place came a group of people who shared my love for heroin. Inadvertently, these hookers, thieves, and ex-convicts became my teachers. From them I became educated about an entirely new way of living.

The transitional phase from surfer to junkie was awkward at times. I recall the repulsion I felt while watching the desperate attempt of a forty-year-old prostitute to inject the drug. She had sores all over her body. Some of them, 
looking like open wounds, contained an oozing, yellowish fluid. Her arms were covered with black-lined tracks, scars from years of addiction. Unable to find a vein, she kept poking herself over and over with the syringe in hopes of getting the drug into her body. Before long, blood was dripping off her elbow onto the floor. When I tried to hand her some toilet paper to wipe herself off, she frantically told me, as she moved the needle in and out of her arm, "I almost got it. I almost got it!" Cleaning the blood off herself was the last thing on her mind at that point. I also recall older males, most who had been to prison, teaching me about "the game" of being an addict. They taught me how to make an "outfit" (tool for injecting the drug) out of plastic tubes and baby pacifiers, and how to sharpen the needle on a matchbook cover when it got too dull. They taught me how to bring somebody around if they happened to overdose. From them I learned that it was only a matter of time before I would be getting locked up, and some hints on what to do when I did.

As a whole, my new associations helped me neutralize or rationalize my actions (Sykes and Matza, 1957), which, very quickly, became the daily use of heroin, along with petty thievery. In this social world it was okay to break the law, it was okay to be a dope fiend, it was okay to go to jail. What was not okay was cooperating with agents of the law for any reason, at any time. Horror stories of what happened to snitches were legend. Those who lived by the rules of the game seemed to live with dignity and were treated with respect. Those who did not were stigmatized or worse.

As predicted, it was not long before I began getting arrested and spending time in jail. The "street-oriented" education I had been exposed to prior to actual incarceration was helpful in making the transition to the social world of confinement. While there, I quickly learned that the majority of those who remained in custody without making bail were also heroin addicts. The guys I came to know on the inside had the same basic worldview as the people I had been hanging out with on the streets. Still, doing time was different than being out.

Prior to being sent to prison, I spent many months in the Santa Barbara and Los Angeles county jail systems of southern California. Paradoxically, these were places I would witness both the best and worst sides of human nature. It was in the Los Angeles County Jail in particular that I became highly informed regarding the art of surviving in an upside down, overcrowded, and unbelievably oppressive environment. 
My experiences in LA County Jail helped to teach me the value of shared suffering. Camaraderie between prisoners, especially in the closed confines of our crowded cells, was always amazing. On one occasion, I was so addicted when I entered that human processing agency (or zoo, which is what it more closely resembles) that I did not sleep a minute for three entire weeks. During that time there were a few other prisoners, total strangers until we met on the tier, who did what they could to ease my misery. Lacking any real appetite, and too weak to make it to the chow hall, these guys supplied me with warm coffee and candy bars - often at their own expense. Typically, it was not until we were moved into more open public spaces, such as the chow hall or recreation yard, that we exhibited feelings of animosity toward each other.

In LA County Jail I also learned that brutality against prisoners is an everyday occurrence. It was there I witnessed guards beating men with flashlights, and heard them screaming endless tirades of disrespect at everyone who was confined - the mentally ill, the severely addicted, the chronically homeless - it did not matter who we were. All of us suffered at the expense of our keepers. We were strip searched, sprayed with DDT to kill whatever bugs might be on our bodies, and herded into cells where the only available place to sleep was on the concrete floor-without a mattress.

We also suffered because we were not always able to get along with ourselves. Prisoner violence was something that could and did erupt on the spur of the moment. Except for the earliest hours of the morning, the cellblocks were always loud. Screaming and yelling were the primary means of communication. One night I remember hearing someone on another tier yelling the universal message that someone has lost consciousness, "Man down. Man down." Once heard, it is expected that guards will hear the call and send help as soon as possible. In response, a prisoner from another cell screamed, "Is he out?" "Yeah," came the reply. Immediately thereafter I heard, "Then roll him over and fuck him." My education in jail was very useful in helping me negotiate my next horizon-prison.

Prison was actually an improvement over the jail conditions I had experienced. Most of all we were given more autonomy. We could attend school, work, or hang out in the yard where we exercised, got high, played cards or dominoes, told endless stories, and laughed $a$ lot. The pervasive prison humor helped us negotiate and manage the gaps between our "normal" and convict identities (Terry, 1997). Because of what I had learned prior to 
arriving, my transition to the prison lifestyle seemed relatively easy. What I did not anticipate, however, was the huge significance of race behind the walls.

In the California system, and elsewhere, there were boundaries between groups that required a thorough understanding because crossing them could lead to violence and death. This was a world where almost everything revolved around an individual's race and where he came from on the streets. Very quickly, I learned that, except in unusual circumstances, whites and browns and blacks kept their distance from each other whenever possible. In the public spaces of prison I saw what amounted to de facto segregation. It was as if certain segments of the chow hall or yard belonged to specific races. Moreover, the groupings of men by race were further splintered based on their place of origin in the outside world: over here was Orange County, over there was the San Fernando Valley. The northern Chicanos were involved in a constant war with Chicanos from the southern part of the state, a battle that continues to this day. Familiarization with these social realities was essential for survival.

In prison I also learned about personal responsibility and integrity. This was not a world where deceit and pretentious projections of self had much longevity. As on the outside, how we were seen by others was related to the people we hung out with and how well we were trusted. Being respected and feared were nearly synonymous. To be seen positively as "solid," or "stand up," was next to impossible for any significant period of time unless one was seen as trustworthy and lived by the tenets of the culture.

The more time I did, the easier it was to live behind bars because I developed a self-concept and a worldview which reflected a convict perspective. The downside of this was that as the years passed it became increasingly difficult to adapt to the outside whenever I was released. While inside I had a secure social network and a positive self-image which allowed me to live with integrity. I knew what to expect, who my enemies were, and how to thrive in that environment. Once released, I felt like a stranger in a strange land. Alienated to the extreme, the only people I could relate to were other addicts or people who had also done time. Ultimately, I always ended up getting hooked on heroin and sent back to prison.

By the time I was 35 years old I found myself sitting against the wall in the Oregon State pen with a few other institutionalized convicts. These were my brothers, my herd. We did everything from working out, eating, getting high and laughing, to showering and shitting together. Though their presence in my life was essential to my well-being, the perspective we shared was extremely 
narrow. We lived in a black and white world where right was right and wrong was wrong. What was right was being under the influence of drugs and living by the rules of the game we had all learned to play. Without knowing it then, this limited world view left me basically cut off from almost all human beings. The game I valued left me isolated from almost everything in life.

\section{THE WAY OUT}

In 1986, I had to do a week in segregation for being under the influence of narcotics. It was there that I managed to read a book called The Source by James Michener. I had always read books while confined, including several Michener books, but the effects of reading The Source at that time had a huge impact on me. It is a book about the history of a specific location in the Middle East, ranging from many thousands of years $\mathrm{BC}$ to the present. As Michener does in all his books, he incorporated fictional stories with historical situations, trends, and people. From that one book I was introduced to the Crusades, the Spanish Inquisition, and much more. Upon its completion I was left with a thought that had never occurred to me before. I realized I enjoyed learning.

At that particular time I had already been incarcerated for just about three years. Along with my newfound awareness that I enjoyed learning, I had also become bored with the monotony of prison life where change is so uncommon. These aspects of my life, among others, motivated me to attend a couple of college classes in the education department. At that time college was an option, supported by Pell Grants from the federal government, which were available to all prisoners who qualified by having a high school diploma or a GED. Since I was working full time in the furniture factory for top pay ( $\$ 3.00$ a day), and highly valued my job, I decided I would take a couple classes, which were available in the evenings, just to see if I was even amenable to school. Today I believe it was a decision that dramatically altered the course of my future.

The first two classes I took were called Cultural Anthropology and Developmental Psychology. Both had the effect of shattering the foundations of my limited knowledge about the world and myself. In the cultural anthropology class I learned about different traditional (non-modern) cultures that had been discovered all over the planet. Each had a distinct meaning system. Each had its own set of values, norms, and lifestyles. In one, for example, babies were raised solely by men for five years after birth. In another, there was no distinction between what we define as cousins and brothers. The single commonality 
among them all was a belief in some force connecting all life. It was amazing for me to be able to see how each worked perfectly within the context in which it was found. What people did was necessary for their survival. And what they did simply worked. From the cultural anthropology class I began to see the world I lived in behind the walls as a unique culture. Implicitly, this meant that there was not only another, but many different ways of living and of seeing the world. Though I did not know it then, my notions of right and wrong and black and white were beginning to crumble.

The developmental psychology class was equally enlightening. Rather than helping me to reconceptualize the social world of the prison, it helped me redefine myself. It was especially interesting for me to hear the teacher go over Erikson's (1963) theory of emotional development. According to Erikson, we internalize certain attributes during various stages of life. In our early years we learn trust versus mistrust, autonomy versus shame and doubt, initiative (self-motivation) versus guilt, and industry (attempt to win recognition by doing good things) versus inferiority. During puberty we either develop a sense of identity or suffer from role confusion. By the time we are young adults we evolve into people who are eager for intimacy or we suffer from a deep sense of isolation and become totally self-absorbed. The implications of the teachers' words rattled me to the core. I knew in my heart that I came out on the negative end of each of Erikson's phases. As the meaning of this new understanding dawned on my consciousness I disrupted the lecture and blurted out, "No wonder I'm a dope fiend! By the time I was a teenager I didn't trust anybody, I was overcome with guilt, shame, doubt, and didn't know who I was! Now, what can I do to quit being a dope fiend?" Chuckling kindly, the teacher suggested I take many more classes in school. I did.

With the aid of financial support from my family, I was able to quit my job and become a full time student for the next two years. The classes I would take during that period provided me with windows into worlds I never knew existed. Courses I took included psychology, sociology, biology, anatomy, algebra, the history of world religions, and several versions of cultural anthropology. And as the classes came and went, the views I had about the world and myself continually changed.

My exposure to that educational environment and all I was learning, amidst the monotony of the prison experience, was stimulating, nurturing, and life enhancing. Instead of hanging out in the furniture factory or the yard thinking about how to hustle another high, I found myself in classrooms with the 
minority of other convicts interested in learning; in my cell reading, studying, and writing. Getting high was still part of my life, but once underway, the educational process had me in its grips almost as powerful as any drug ever had. I recall one time when I was taking an anatomy class having to memorize ten pages of notes for a test. I would be out in the yard pulling these pieces of paper out of my pocket, going over them, repeating three of four words at a time until I had it all memorized. And in the education department I would see other guys I knew. We hung out in the smoking room between classes and talked trash like we had been doing for years. But we also talked about history, biology, and psychology. One friend and I used to call each other "doctor" as we passed each other in the hallway of the education department or on the tier. We joked about being convict scholars. It was almost as if it was not okay to be doing what we were doing, that we were unworthy or incapable of becoming educated. Such thoughts, of course, were merely reflections of the meanings we had learned in the prison culture and of our convict identities.

The teachers who came to the prison were influential in ways beyond being educators. The main reason for this, I believe, is that unlike almost everybody else who works in the criminal justice system, they treated us like human beings. While in those classrooms it was almost like being somewhere in the free world. In the presence of these teachers we were not degraded for simply existing. Ken Jensen, the guy who taught cultural anthropology, was also the college program coordinator. Bright, shy, friendly, and selfless in his actions, he was a tremendous inspiration to many of us. Often I would make him blush with my crude, convict-oriented humor about some particular topic he was discussing. Ken's many years teaching at Oregon State Penitentiary (OSP) spawned his interest in criminology-related studies, especially about programs that have the potential to help prisoners turn their lives around. We have remained in contact over these many years and occasionally see each other at academic conferences.

The teacher who taught developmental psychology also had a huge affect on me. Again, it was not just what he was teaching, but also his style of interpersonal relations with us that really got my attention. He treated us with decency, respect, and obvious compassion. And he did so every single time he came. This was strange territory for me-unchartered waters. One evening, as I sat listening to him lecture during class, an alien thought crossed my mind. While observing him I noticed he looked happy. And when I considered his disposition over time, I realized he always seemed happy. This contradicted 
my reality because, for me, to be happy meant to be high. The next thought that came to me was, "this guy looks happy and I know he's not loaded." In retrospect, I can never recall noticing another human being as being happy before that night in school; that is, unless that other person was high. Once this occurred to me I thought, "I wonder what it would be like to be able to be happy without having to be high?"

After those years in college I had the opportunity to be transferred to a minimum-security forest camp near the Oregon coast because I was nearing my release date. The transition from OSP was severe at first, but I adapted. While in that camp I learned how to cut trees down with chain saws, which was a total blast. It was there that I was also introduced to literature related to spirituality.

A friend of mine from OSP, who had embarked on a journey to expand his own horizons, gave me access to his personal book collection. Much of what he had gathered contained works related to eastern philosophy and mysticism. In a way they acted as an extension of what I had already been learning in the prison college classes. They taught me more about another way of seeing the world, and about ways and means of attaining inner peace. For example, in Stephen Levine's A Gradual Awakening I learned about the value of letting go of efforts to control things outside of ourselves. Krishnamurti (1969) helped me realize why human beings are attracted to anger and violence and how, ultimately, our notions of reality stem from the way our minds have been conditioned by our methods of education and culture. From Ram Dass (1974) I was reminded of the four noble truths of Buddhism, which I had first heard about in a world religion class at OSP. Basically, what they teach us is that suffering is at the heart of the human condition. We suffer because we have desires. Freedom from suffering comes from releasing those desires; the hard part is that in order to really be free from suffering, we have to actually let go of our own expectations, demands, and self-conceptions which, based on the ways we have been conditioned from birth, determine the things we desire or not.

My interest in this literature and what it represented provided me with both the means and motivation to spend a significant amount of time meditating during my last year of incarceration. In an effort to quiet my mind, I would sit in the back of the cell, stuff my ears with foam plugs smuggled from the metal shop to lessen the noise, and pull a wool beanie over my eyes to block the light. With continued practice, I managed to locate a place of deep calm within 
myself that I never knew existed before. In this place there was no fear, no doubt, no difference, and no uncertainty about anything. In this place there were no names, time lines, or other borders which characterize the separating attributes of the world. As the writers of the books I had been reading said, in this place was only oneness and a deep sense of peace. The feeling I experienced while meditating was somewhat familiar to the way I felt while under the influence of a strong shot of heroin. The difference, however, was that the more heroin I used the more I needed to get to that place. On the other hand, the more I meditated, the easier it was to get there and the harder it became to leave. Moreover, each time I came back to "reality" things were just a little more pleasant and a little less hectic than they had been before.

Experiencing peace while meditating was great. But I quickly learned that any peace I gained in the cell could be lost in an instant on the tier, in the chow hall, or on the yard. The books I was reading said that we create the way we feel based on what we bring to the circumstances we encounter. Ultimately, we receive what we give, always, at all times. When we give anger, we get anger. When we give love, we get love in return. It was for this reason that I began making efforts to watch my thoughts as they emerged during my daily activities. Of special concern to me were the situations and events that propelled me toward anger and hostility toward others.

Ironically, the people I hated the most became my most valued teachers. Though I never said a word to any of them, they helped me become a freer, happier person. For example, there was one guy in OSP who had been convicted of kidnapping, raping, and murdering women in California, Oregon, and Washington. After having his way with them, the story went, he would leave their bodies on Interstate 5. He was well known and despised by a majority of the prisoners. When I did time in California, people like him were kept in protective custody. In Oregon he remained in the general population with everyone else. Not only that, he carried himself with an air of superiority. One day I was hanging out with a friend in the yard. As we did on many occasions, we were walking around the track, talking as we went. In my guts, on the inside where I live, I felt okay, calm. The world was a decent place to be. Suddenly, I looked up and saw this I-5 guy walking in our direction. It was not like he was heading toward us in particular. He was merely part of the crowd walking in the opposite direction. Instantly, as soon as I laid eyes on him, I felt the familiar feelings of hatred, anger, and rage, and they were all aimed directly 
at him. It was not like I was trying to feel this way. I just did. I hated this guy. From my perspective he was no good and did not deserve to breathe.

Unlike the untold number of times I had experienced similar feelings in relation to other people or situations, on this particular occasion I became somewhat conscious of what was happening. The understanding that followed was overwhelming. I realized that my hatred toward this man had no effect on him whatsoever. Instead, I was the one experiencing the effects of my hatred. In fact, I learned when it comes to the way we feel, we really do get what we give. I gave hatred, I received hatred. It was quite an eye opener for me to realize that this is what is happening all the time, throughout the world with all of us. I could be in C-block and suddenly get angry over the three packs of cigarettes a guy in D-block owed me, and I would feel the anger! What this meant, in short, is that holding onto resentments is like taking poison and waiting for the other guy to die. This awareness had a huge effect on me. It helped me reduce the amount of pain I caused myself by judging others negatively because they do not happen to live up to my expectations and demands. By the time I left that institution I was able to pass the I-5 guy without experiencing the toxic effects of my anger. It was not that I could go up to him and give him a hug, but his existence no longer caused me to suffer as it had in the past. For me this was evidence of the possibility that there really was a "way out." And that "way" did not necessarily have anything to do with being diagnosed as healthy by a prison shrink or deemed eligible for release by a parole board.

The only time I got high during that last year was when somebody "kicked me down" for free. By then, trying to get high had become too much of a hassle. It was overly expensive, time consuming, and seldom worth it. Along with exercising and meditating, I ate and slept well, and (since I was thoroughly institutionalized by then) had little to worry about in life. Further, while getting high felt good, it typically took me several days to get back to normal after the dope wore off. Without realizing it, I was learning that feeling normal felt good.

Ninety days before my last parole, my cellie brought home enough heroin for us both. I was excited, to say the least. What awaited me, however, was something I never anticipated. The first thing I thought after feeling the euphoric effect of the drug was, "God, I can't believe I screwed my whole life up for this feeling." Somehow, it just was not what it had always been. Within the next instant I experienced what is often referred to as a "moment of clarity." 
What came to me seemed clear and unequivocal. I thought, "This stuff isn't giving me anything. In fact, it's taking away from what I have." Implicitly, this meant that being clean would be better than being high. It seems to me today that "what I had" was something that had been hidden from my awareness most of my life. It took everything I had undertaken prior to that point in time, especially the years I spent in college, the books I read at the forest camp, and the time I spent meditating and watching my thoughts, to learn that what I "have" is what everyone else has: the potential to feel joy, happiness, and a sense of inclusion with those around us. Unfortunately, it is impossible to experience these human qualities when we are immersed in fear, anger, hatred, and feelings of exclusion and difference.

\section{Conclusion}

As I look back at my life today, it seems clear that the effects of what I began learning in those college classes at OSP were nothing less than transformational. More than anything, perhaps, I began seeing myself within a much broader context than I ever had before. My interests in spirituality, which followed, built upon and reinforced this major perceptual shift. In addition, I started thinking more critically, seeking answers to questions that were, to me, as yet unanswered.

Prior to being released I decided I would try to pursue a formal education after I got out. My thinking in this regard was simple: "I know I'm institutionalized. I do well in institutions. Colleges on the streets are institutions. Since I do well here maybe I could do well there." Of course, "doing good" meant staying out, something I had never done for more than three years since I was eighteen years old. As fate would have it, my plan worked beyond my wildest expectations. Along with a tremendous amount of social support from my family, as well as friends in twelve-step programs and academia, came

opportunities which I took advantage of, the motivation to continue learning, and a whole new way of life. As the journey has evolved I have had the privilege to begin the wonderful experience of acting as teacher myself.

Today I am employed as a college professor who teaches classes about criminology, law, and society. I do my best to educate students about the ludicrous nature of the harsh, revenge based realities of state sponsored social control. In other words, I teach about the system of criminal injustice as a whole, ways it benefits big business, and how it is legitimized by politicians, 
the media and members of law enforcement who indoctrinate the public with the fear of crime and the need for public safety. The combination of bringing my extensive education and experience within the system to the classroom seems to work quite well. It also seems to enhance my credibility with students. It is one thing to lecture about prison, for example, using notes from what is often dry, empty literature filled with statistics, and quite another when you can juxtapose academic material with real life stories because in fact you have actually "been there."

Over the years I have developed relationships with other ex-convicts who have undergone a journey similar to my own. All of us have been to prison. All of us either have completed, or are working toward a Ph.D. This group, which is becoming known as the "New School of Convict Criminology" is becoming stronger and growing over time. Though our interests and views vary considerably, we do what we can to inform others about issues related to social justice from a convict perspective. The foundation of our work stems from our experiences. These not only set us apart from mainstream academics and practitioners, but also make us a potential threat. We talk about what is wrong with and missing from professional literature about criminal justice and "corrections"; about how our views differ from those without "insider" status; about the obstacles we faced along the rocky roads toward becoming college professors; and about suggestions for reform that would enhance the experiences of people currently caught up in the system (See Richards and Ross, this issue).

Convict criminology provides a vision that needs further support. Rather than controlling prisoners, which is the primary focus of the criminal justice system, we advocate efforts to reduce the prison population by cutting back on lengthy sentencing guidelines and ending the war on drugs. We also support voting rights for all convicts and felons, better living conditions for prisoners, an end to the use of prison snitches, and increased opportunities for higher education behind bars. Moreover, we agree with others who suggest that supervision by the state upon release from custody should be entirely eliminated for the majority of individuals, or at least greatly shortened (Austin, 2001).

Along this journey I have discovered that we all have a window through which we see the world. All the meanings we give to everything in our lives stem from what we see through the glass. The window I used to look through was dark and murky. What I saw was limited to the extreme and highly distorted. This murkiness, though still there to some degree, has diminished along with 
my education. The hard part to deal with is that the clearer the picture gets the more painful it is to see. In other words, the more we learn, the more aware we become of injustice, inequality, death, and suffering which affect huge numbers of human beings who inhabit our planet. And the more we learn, the more we develop a sense of responsibility to do something to make the world a better place.

A few years back I was eating lunch with Alan Mobley and John Irwin, two other ex-convicts who earned $\mathrm{Ph}$.D.s. John, who is now a retired professor and has authored many books about prisons, is like the gang leader of convict criminology. At some point in the discussion, Alan and I touched upon the seeming worthlessness of the battle we are engaged in today. Trying to right the wrongs of the law, the criminal justice system and the forces that support them, seems to be an insurmountable task. John, with his ever-present wisdom, responded by saying, "Yeah, but we gotta keep up the fight. If our ancestors hadn't fought the fight we'd all be slaves right now." He may very well be right.

As it has been for me, education can lead to ways out of negative, selfdestructive lifestyles. It can also be a way to bring about social change. The worst we can do is to be apathetic about the way things are. The most we can do depends on our abilities, opportunities, and actions. What we do, and the future we create, is up to us all.

\section{REFERENCES}

Austin, J. (2001). "Prisoner Reentry: Current Trends, Practices, and Issues." Crime and Delinquency, 47:3, 314-334.

Dass, R. (1974). The Only Dance There Is. Garden City: Anchor Books.

Erikson, E.H. (1963). Childhood and Society ( $2^{\text {nd }}$ edition). New York: W.W. Norton.

Fromm, E. (1976). To Have or to Be. New York: Harper and Row.

Krishnamurti, J. (1969). Freedom from the Known. San Francisco: Harper Collins.

Levine, S. (1979). A Gradual Awakening. Garden City: Anchor Books.

Sykes, G.M., and Matza, D. (1957). "Techniques of Neutralization: A Theory of Delinquency." American Sociological Review, 22: 664-673.

Terry, C.M. (1997). "The Function of Humor in Prison." Journal of Contemporary Criminal Justice, 13:1, 23-40.

Charles Terry is an ex-convict and former heroin addict who now works as an assistant professor in the Department of Sociology and Criminal Justice at 
St. Louis University. His research incorporates a critical, ethnographic approach to illustrate issues of social injustice and healing. He pays particular attention to the perspectives of those who get caught up in the criminal justice system: how they make sense of their worlds, and what they do to maintain dignity and self-respect. He may be contacted at Sociology and Criminal Justice, 3500 Fitzgerald Hall, Rm. 205, 3500 Lindell Blvd., St. Louis, MO 63103. 